\title{
MERCURY POISONING ON GOLD MINERS AT ARTISANAL AND SMALL-SCALE GOLD MINING IN INDONESIA:A SYSTEMATIC REVIEW
}

\author{
Arinil Haq ${ }^{1 *}$ and Umar Fahmi Achmadi ${ }^{1}$ \\ ${ }^{1}$ Faculty of Public Health, Universitas Indonesia
}

\begin{abstract}
Mercury ( $\mathrm{Hg}$ ) is a natural element that can be found in air, water and soil. However, various activities may increase mercury levels including artisanal and small-scale gold mining (ASGM) activities. Mercury is toxic and persistent that it can harm humans and the environment. The use of mercury in ASGM process can have negative effects on gold miners, one of which is mercury poisoning. Therefore, it is important to know what factors are related with the occurrence of mercury poisoning on gold miners at ASGM. Beside that, there are many studies on mercury poisoning in Indonesia. This research is a systematic review of 5 eligible research journals conducted in the year 2000-2017 in Indonesia. Journals are obtained from Science Direct, Google Scholar and Portal Garuda databases. Factors that are often researched in these studies are age, nutritional status, working hours per day, working frequency per week, working period (years), mercury levels used per day, the use of Personal Protective Equipment (PPE), and fish consumption. Based on a systematic study, most journal finds that the hours worked per day, working frequency per week, working period (years), and the use of PPE are significantly related to mercury poisoning. While, age, nutritional status, mercury levels used per day, and fish consumption have no statistically significant relationship with the occurrence of mercury poisoning on gold miners at ASGM in Indonesia.
\end{abstract}

Keywords: mercury poisoning, gold miners, artisanal and small-scale gold mining

\section{Introduction}

According to the World Health Organization (WHO), mercury is one of chemicals group that is a major concern of public health. Mercury exposure, even small amounts can cause serious health problems (World Health Organization, 2017). Mercury has toxic effects on the nervous system, kidneys, and cardiovascular system. Other affected systems include respiratory, digestive, hematological, immune, and reproductive systems (United Nations Environment Programme, 2008).

Mercury can be found in environments in very low concentrations (Gohari, 2016). However, mercury levels can be increased through various types of human activities, one of which is gold mining activities, especially artisanal and small-scale gold mining (ASGM). The mercury element is used to obtain a mercury-gold alloy called "amalgam". There are two main methods used in ASGM for amalgamation, which is the amalgamation of whole ore and the incorporation of the concentrate. In amalgamation of whole ore, mercury is added with little comminution and concentration. A large amount of mercury is often used and most of it is released as waste into the mine tailings due to the inefficiencies resulting from this process (Sousa et al., 2010; United Nations Environment Programme, 2015).

Artisanal and small-scale gold mining (ASGM) or illegal gold mining in Indonesia is still growing, especially in the last decade where the price of gold is increasing compared to the 1980 s. There are currently about 250,000 miners without permits and about 1 million other workers are involved in this activity. According to collective estimates, these unlicensed miners could produce about 60 tonnes of gold annually (Sembel, 2015) 
Miners at ASGM who directly contact with mercury are at risk for the occurrence of mercury poisoning. Poisoning can occur acutely or chronically. Acute mercury poisoning shows symptoms of pharyngitis, abdominal pain, nausea and vomiting accompanied by blood and shock. If not treated immediately, will continue with the swelling of the salivary glands, nephritis, and hepatitis. While chronic poisoning can continue in the form of disturbances of the digestive system and the nervous system or gingivitis (Widowati, Sastiono, \& Jusuf R, 2008).

Research about mercury poisoning on gold miners at ASGM has been numerously done in Indonesia and some of which have been published. Therefore, this study uses a systematic review approach, which can summarize the results of primary research to present a more comprehensive and balanced fact (Siswanto, 2010). This study aimed to analyze factors related to mercury poisoning on gold miners at ASGM in Indonesia.

\section{Method}

This study is a systematic review of some literature that examines the factors relationship with mercury poisoning on gold miners at ASGM. The results of this study were reported in accordance with Preferred Reporting Items for Systematic Reviews and Meta-Analyzes statement (PRISMA). The research results obtained from the data-based search are shown in Figure 1.

The studies included are studies that have been published from 2000 to 2017 on data based Science Direct, Google Scholar and Portal Garuda using the keywords: "mercury poisoning AND gold miners AND Indonesia". We consider the inclusion criteria that we use ie the location of the research is in Indonesia. The research was conducted on gold miner at ASGM in Indonesia. We issued studies conducted before the year 2000, which is not journal article, not using Indonesian or English, and purchased journal. This study was conducted by two people. Our first step was to create a systematic review protocol. And then, first author reviewing abstracts and manuscripts from several studies based on eligibility criteria. Second author reviewed the results and together we wrote the results and discussion.

We identified 236 studies that were obtained through electronic literature searches and reviewed through a systematic review flow chart. After removed duplicate articles by title, 232 articles were obtained. The next stage is screening the abstracts with inclusion and exclusion criteria then got 14 articles. For the purposes of further analysis, the selection of articles based on fulltext that can be accessed. After eligibility selection, 9 articles are purchased, and in final 5 articles that free access can be reviewed. 

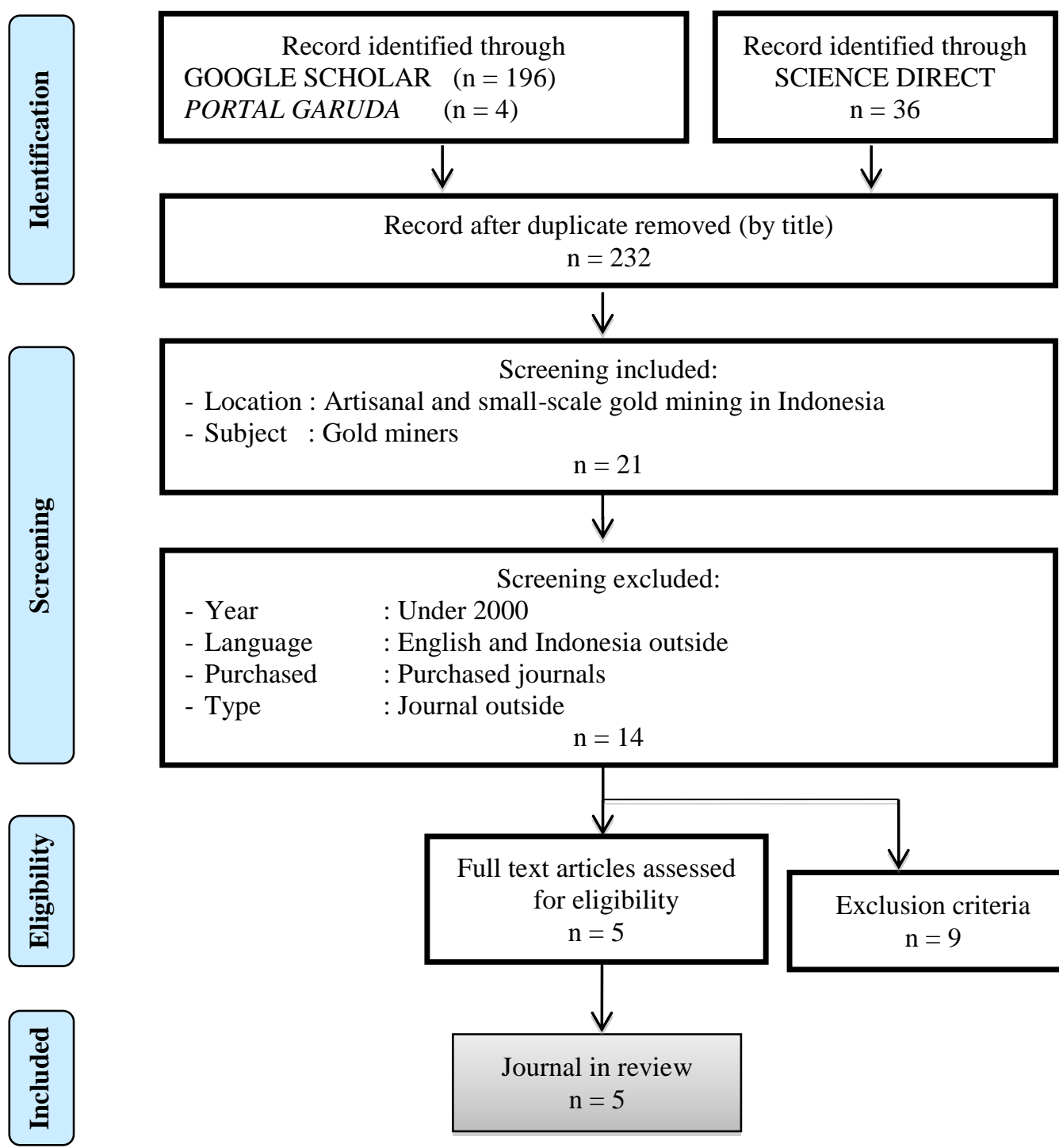

Screening included:

- Location : Artisanal and small-scale gold mining in Indonesia

- Subject : Gold miners
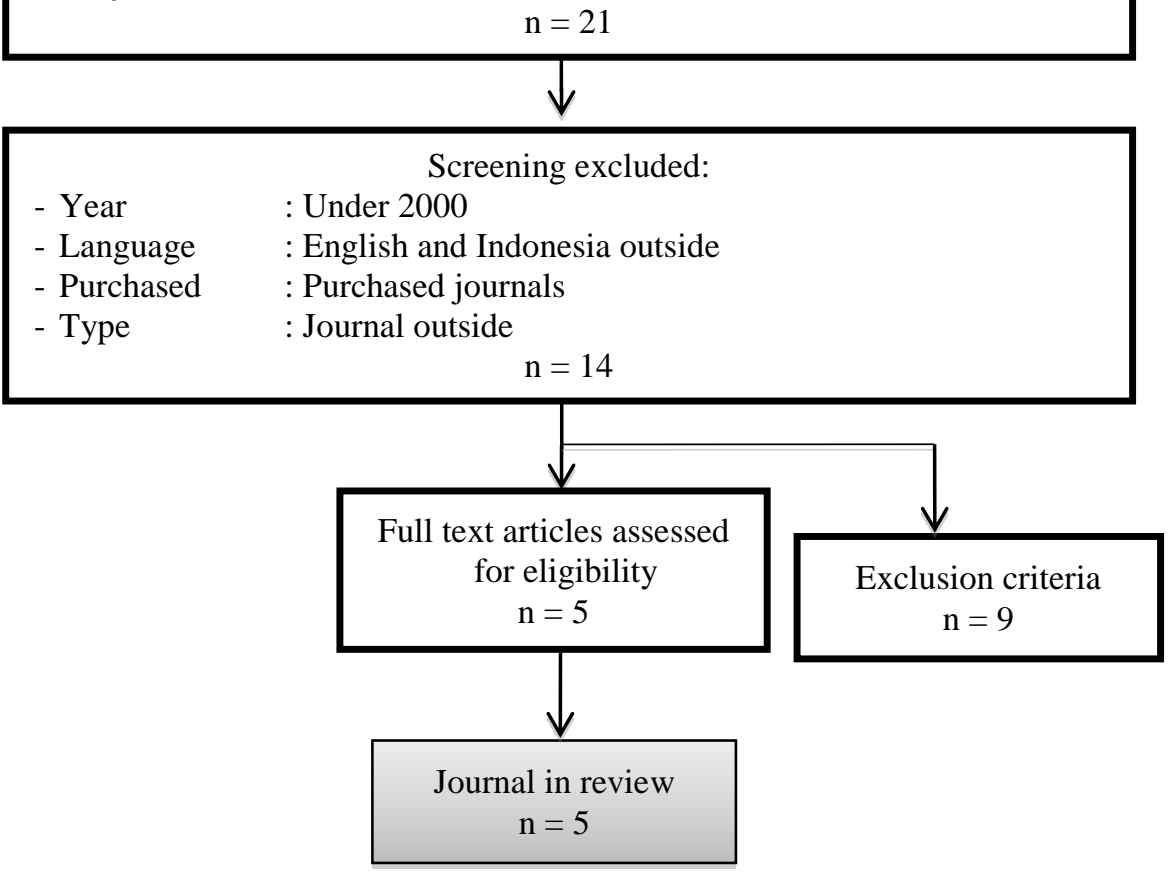

Figure 1.Preferred Reporting Items for Systematic Reviews and Meta Analysis (PRISMA) 2009 Flow Diagram Showing Study Selection Process

\section{Results}

\section{Study characteristics}

One study was published in 2009 (Wardiyatun \& Hartini, 2009), 2 studies in 2012 (Petasule, 2012; Rianto, Setiani, \& Budiyono, 2012), 1 study in 2014 (Sumantri, Laelasari, Junita, \& Nasrudin, 2014), and another in 2015 (Asiah, Alfian, Anwar, Siregar, \& Bangun, 2015). Research sites in these studies are in Wonogiri District, North Gorontalo District, Ketapang District, South Aceh District, and Bogor District. All selected studies used cross-sectional study design. The variables studied in these studies are age, nutritional status, working hours per day, working frequency per week, working period (years), mercury levels used per day, the use of PPE, and fish consumption.

Total of 177 gold miners as research participants in these studies. The age range of participants between 17 to 68 years and all male. Mercury levels are measured through different biomarkers in these studies. Two studies measured levels of mercury in urine as a biomarker (Asiah et al., 2015; Wardiyatun \& Hartini, 2009), 2 studies 
measuring mercury levels in hair (Petasule, 2012; Sumantri et al., 2014), and 1 study measuring mercury in blood (Rianto et al., 2012).

\section{Measurement of mercury poisoning}

Based on research conducted by Rianto et al (2012), it is known that $40 \%$ of the study respondents experienced mercury poisoning (Rianto et al., 2012). Two other studies found that $82.8 \%$ and $60 \%$ of respondents experienced mercury poisoning (Petasule, 2012; Sumantri et al., 2014). While 1 study found 27.8\% of respondents had mercury poisoning (Wardiyatun \& Hartini, 2009) and 1 study found that mercury levels in urine were still below the threshold value (Asiah et al., 2015).

\section{Demographic factors}

The results of two studies examining the relationship of age with mercury poisoning, there was no significant relationship between age and mercury poisoning (Sumantri et al., 2014; Wardiyatun \& Hartini, 2009). While one study examining the relationship of nutritional status with mercury poisoning found that there was no significant relationship between nutritional status and mercury poisoning (Wardiyatun \& Hartini, 2009).

\section{Occupational factors}

Occupational factors studied were related to working time, based on working hours per day, working frequency per week, and working period (years). Three out of four studies examining the working hours per day relationship with mercury poisoning resulted in a significant association between working hours per day and mercury poisoning ( $\mathrm{p}$-value $=0.046,0.047,0.045$ ) (Petasule, 2012; Rianto et al., 2012; Wardiyatun \& Hartini, 2009). One of the 2 studies examining the working frequency relationship per week with mercury poisoning found that there was a significant relationship between working frequency per week and mercury poisoning (pvalue $=0.021$ ) (Rianto et al., 2012). Three out of 5 studies have found that there was a significant relationship between working period (years) and mercury poisoning (p-value $=0.046 ; 0.001 ; 0.001$ ) (Asiah et al., 2015; Sumantri et al., 2014; Wardiyatun \& Hartini, 2009)

\section{Behavioral factors}

Some of the behavioral factors studied were the amount of $\mathrm{Hg}$ used per day, the use of PPE, and fish consumption. Two studies examining $\mathrm{Hg}$ per day found no significant association between mercury levels used per day and mercury poisoning (Petasule, 2012; Rianto et al., 2012). Two of the 3 studies that examined the use of PPE found that there was a significant relationship between the use of PPE and mercury poisoning ( $\mathrm{p}$-value = 0.022; 0.001) (Petasule, 2012; Wardiyatun \& Hartini, 2009). While 1 study on fish consumption found that there was no significant relationship between fish consumption and mercury poisoning (Sumantri et al., 2014).

\section{Discussion}

\section{Main findings}

The result of this systematic review is that in two studies most gold miners (more than 50\%) in these studies experienced mercury poisoning that known from mercury levels in biomarkers. However, the gold miners have not experienced symptoms or health problems. Even though, the information is an indication that must be watched carefully and need better prevention efforts to prevent possible health effects (Petasule, 2012; Rianto et al., 2012; Sumantri et al., 2014). This result is in line with research conducted by Mensah et al (2012) who found that $46.65 \%$ of workers identified exposed to mercury (Mensah et al., 2016). 
Two studies examining the relationship of age with mercury poisoning resulted in no significant association between age and mercury poisoning (Sumantri et al., 2014; Wardiyatun \& Hartini, 2009). Age is indicated to affect the presence of mercury in the body, as the age increases, the greater the risk of accumulation of mercury exposure. Especially at the age of growth because the organs are still in the process of growth both function and size so vulnerable to substances that enter the organs of the body such as kidneys, liver and brain. Likewise in the elderly due to stepping old age the function of the organs of the body is decreased (Wardiyatun \& Hartini, 2009). Gold miners in 2 studies are known to be in productive age so that after investigation, there is no relationship between age with mercury poisoning in the two studies.

One article examining the relationship of nutritional status with mercury poisoning found that there was no significant relationship between nutritional status and mercury poisoning (Wardiyatun \& Hartini, 2009). Mercury has fat-soluble properties, so people who have high levels of fat in the body will affect the absorption and excretion of mercury in the body (Andri, Anies, \& Suharyono, 2011). However, the depiction of nutritional status through BMI calculations has a disadvantage if it is associated with mercury levels with long-term exposure because the BMI may change at any time (Wardiyatun \& Hartini, 2009).

Three out of 4 studies examining the working hours per day relationship with mercury poisoning resulted in a significant relationship between working hours per day and mercury poisoning (p-value $=0.046,0.047,0.045$ ) (Petasule, 2012; Rianto et al., 2012; Wardiyatun \& Hartini, 2009). The normal working hours are 40 hours a week or 8 hours a day with 5 working days. The longer the gold miners work the longer the duration for exposure to mercury elements and compounds, thereby allowing greater absorption of mercury by the body either through inhalation or absorption and the greater the accumulation (Wardiyatun \& Hartini, 2009).

One of the 2 studies examining the working frequency per week relationship with mercury poisoning found that there was a significant relationship between working frequency per week and mercury poisoning ( $\mathrm{p}$-value = 0.021) (Rianto et al., 2012). The average number of working days in the study is 5.65 days per week. This condition contributes to continuous exposure from day to day, potentially giving chronic effects on nerve and liver kidney organs (Palar, 1994).

Three out of 5 studies have found that there is a significant relationship between years of service (years) and mercury poisoning (p-value $=0.046 ; 0.001 ; 0.001$ ) (Asiah et al., 2015; Sumantri et al., 2014; Wardiyatun \& Hartini, 2009). The longer the working period (years) will increase the risk of mercury poisoning in the miners. Length of working period (years) has the potential to occur bioaccumulation of mercury in the miner's body (Darmono, 2009)

Two studies examining mercury levels used per day found no significant association between mercury levels used per day with mercury poisoning (Petasule, 2012; Rianto et al., 2012). Although mercury levels used per day is not statistically significant, the use of mercury can be absorbed through the body and pollute the environment. A large amount of mercury released from the tailings, produces tiny droplets of mercury that are too scattered to catch. This causes contamination in the environment and is very difficult to clean (Telmer \& Stapper, 2012).

Two of the 3 studies that examined the use of PPE found that there was a significant relationship between the use of PPE and mercury poisoning ( $\mathrm{p}$-value $=0.022 ; 0.001$ ). The use of PPE is intended to minimize the level of mercury exposure and avoid or reduce the risk of harm caused by mercury. So the more rare or never or incomplete use of PPE, the greater the risk of exposure to mercury and the greater the amount of mercury in the body that accumulates (Petasule, 2012; Wardiyatun \& Hartini, 2009).

One study on fish consumption found no significant relationship between fish consumption and mercury poisoning (Sumantri et al., 2014). people with consumption patterns of eating fish 3-4 times a week are 10 times more likely to have mercury in the blood greater than $1.5 \mu \mathrm{g} / \mathrm{dl}$ compared with people who only eat fish 1-2 
times a week (Setiyono \& Djaidah, 2012). But not in line with this study caused by the fish consumed not from the research site.

\section{Limitations}

Our systematic review found that research on mercury poisoning has been widely practiced, but partly in the form of grey literature excluded in this study.

\section{Conclusion}

Based on this systematic review, most journal finds that the working hours per day, working frequency per week, working period (years), and the use of PPE are significantly related to mercury poisoning. While, age factor, nutritional status, $\mathrm{Hg}$ amount per day, and fish consumption did not have statistically significant relationship with the occurrence of mercury poisoning at gold miner at ASGM in Indonesia. Although, the gold miners have not experienced symptoms or health problems, this information is an indication that we must remain aware and need better coping efforts to prevent the occurrence of health effects that may occur due to mercury poisoning.

\section{Acknowledgements}

Authors express gratitude to Allah SWT who has given the grace and opportunity to write this paper. Thanks to the Universitas Indonesia that has provided funding for this research through HIBAH PITTA.

\section{References}

Andri, D., Anies, \& Suharyono, H. (2011). Kadar Merkuri pada Rambut Masyarakat di Sekitar Penambangan Emas Tanpa Ijin. Media Medika Indonesiana, 45(111), 181-187.

Asiah, N., Alfian, Z., Anwar, J., Siregar, Y., \& Bangun, D. (2015). Pengaruh Lama Kerja terhadap Kadar Merkuri (Hg) dalam Urin pada Pekerja Tambang Emas (Studi Kasus di Desa Panton Luas Kecamatan Sawang Kabupaten Aceh Selatan). Jurnal Pendidikan Kimia, 7(2), 7-12.

Darmono. (2009). Farmasi Forensik dan Toksikologi. UI Press.

Gohari, H. (2016). New Method for Determination of Mercury in Contaminated Water by using Nano Composite Carbon Paste Electrode. Austin Journal of Analytical and Pharmaceutical Chemistry, 3(4).

Mensah, E. K., Afari, E., Wurapa, F., Sackey, S., Quainoo, A., Kenu, E., \& Nyarko, K. M. (2016). Exposure of Small-Scale Gold Miners in Prestea to Mercury, Ghana, 2012. The Pan African Medical Journal, 25(Supp 1), 6. https://doi.org/10.11604/pamj.supp.2016.25.1.6171

Palar, H. (1994). Pencemaran dan Toksikologi Logam Berat. Jakarta: Rineka Cipta.

Petasule, S. (2012). Faktor-faktor yang Berhubungan dengan Kejadian Keracunan Merkuri pada Pemijar dan Pengolahan Emas di Tambang Emas Desa Hulawa Kecamatan Sumalata Timur Kabupaten Gorontalo Utara Tahun 2012. Public Health Journal Universitas Gorontalo, 1-10.

Rianto, S., Setiani, O., \& Budiyono. (2012). Analisis Faktor-Faktor Yang Berhubungan dengan Keracunan Merkuri Pada Penambang Emas Tradisional di Desa Jendi Kecamatan Selogiri Kabupaten Wonogiri, 11(1), 5460.

Sembel, D. T. (2015). Toksikologi Lingkungan. Yogyakarta: Andi Offset.

Setiyono, A., \& Djaidah, A. (2012). Konsumsi Ikan dan Hasil Pertanian terhadap Kadar Hg Darah. Jurnal Kesehatan Masyarakat, 7(1), 110-116. https://doi.org/http://dx.doi.org/10.15294/kemas.v11i1.3467

Siswanto. (2010). Systematic Review Sebagai Metode Penelitian Untk Mensintesis Hasil-Hasil Penelitian. Buletin Penelitian Sistem Kesehatan, 13(4), 326-333.

Sousa, R. N., Veiga, M. M., Klein, B., Telmer, K., Gunson, A. J., \& Bernaudat, L. (2010). Strategies for Reducing The Environmental Impact of Reprocessing Mercury-Contaminated Tailings in The Artisanal and 
Small-Scale Gold Mining Sector: Insights from Tapajos River Basin, Brazil. Journal of Cleaner Production, 18(16-17), 1757-1766. https://doi.org/10.1016/j.jclepro.2010.06.016

Sumantri, A., Laelasari, E., Junita, N. R., \& Nasrudin. (2014). Logam Merkuri pada Pekerja Penambangan Emas Tanpa Izin. Jurnal Kesehatan Masyarakat Nasional, 8(8), 398-403.

Telmer, K., \& Stapper, D. (2012). Reducing Mercury Use in Artisanal and Small-scale Gold Mining - A Practical Guide. United Nations Environment Programme.

United Nations Environment Programme. (2008). Guidance for Identifying Populations at Risk from Mercury Exposure. Geneva: World Health Organization.

United Nations Environment Programme. (2015). Developing a National Action Plan to Reduce, and Where Feasible, Eliminate Mercury Use in Artisanal and Small Scale Gold Mining: Working Draft. Geneva: World Health Organization.

Wardiyatun, S., \& Hartini, E. (2009). Faktor-faktor yang Berhubungan dengan Kadar Merkuri dalam Urine pada Pekerja Tambang Emas di Desa Rengas Tujuh Kecamatan Tumbang Titi Kabupaten Ketapang Kalimantan Barat. Jurnal Visikes, 8(2), 132-142.

Widowati, W., Sastiono, A., \& Jusuf R, R. (2008). Efek Toksik Logam. Yogyakarta: Andi Offset.

World Health Organization. (2017). Mercury and Health. Retrieved from http://www.who.int/mediacentre/factsheets/fs361/en/ 